\title{
Front Matter: Volume 9258
}

, "Front Matter: Volume 9258," Proc. SPIE 9258, Advanced Topics in Optoelectronics, Microelectronics, and Nanotechnologies VII, 925801 (24 February 2015); doi: 10.1117/12.2189945

SPIE Event: Advanced Topics in Optoelectronics, Microelectronics, and SPIE. Nanotechnologies 2014, 2014, Constanta, Romania 


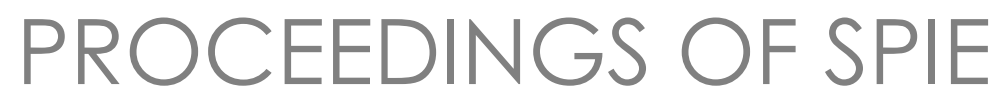

\title{
Advanced Topics in Optoelectronics, Microelectronics, and Nanotechnologies VII
}

\author{
Ionica Cristea \\ Marian Vladescu \\ Razvan Tamas \\ Editors
}

\section{1-24 August 2014 \\ Constanta, Romania}

\section{Organized by}

Politehnica University of Bucharest-Optoelectronics Research Center (Romania)

Constanta Maritime University (Romania)

Sponsored by

Romanian Ministry of Education (Romania) • Politehnica University of Bucharest (Romania) Constanta Maritime University (Romania) • Teamnet International (Romania) • ADVI TECH Consulting SRL (Romania) • SOEL Systems SRL (Romania) • ELECTROMAGNETICA S. A. (Romania) • WING Computer Group SRL (Romania) • Agilrom Scientific (Romania)

Cooperating Organization and Publisher

SPIE 
The papers included in this volume were part of the technical conference cited on the cover and title page. Papers were selected and subject to review by the editors and conference program committee. Some conference presentations may not be available for publication. The papers published in these proceedings reflect the work and thoughts of the authors and are published herein as submitted. The publisher is not responsible for the validity of the information or for any outcomes resulting from reliance thereon.

Please use the following format to cite material from this book:

Author(s), "Title of Paper," in Advanced Topics in Optoelectronics, Microelectronics, and Nanotechnologies VII, edited by Ionica Cristea, Marian Vladescu, Razvan Tamas, Proceedings of SPIE Vol. 9258 (SPIE, Bellingham, WA, 2015) Article CID Number.

ISSN: 0277-786X

ISBN: 9781628413250

Published by

SPIE

P.O. Box 10, Bellingham, Washington 98227-0010 USA

Telephone +1 3606763290 (Pacific Time) · Fax +1 3606471445

SPIE.org

Copyright (@ 2015, Society of Photo-Optical Instrumentation Engineers.

Copying of material in this book for internal or personal use, or for the internal or personal use of specific clients, beyond the fair use provisions granted by the U.S. Copyright Law is authorized by SPIE subject to payment of copying fees. The Transactional Reporting Service base fee for this volume is $\$ 18.00$ per article (or portion thereof), which should be paid directly to the Copyright Clearance Center (CCC), 222 Rosewood Drive, Danvers, MA 01923. Payment may also be made electronically through CCC Online at copyright.com. Other copying for republication, resale, advertising or promotion, or any form of systematic or multiple reproduction of any material in this book is prohibited except with permission in writing from the publisher. The CCC fee code is 0277-786X/15/\$18.00.

Printed in the United States of America.

Publication of record for individual papers is online in the SPIE Digital Library.

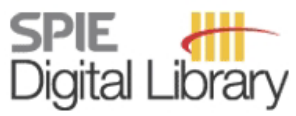

SPIEDigitalLibrary.org

Paper Numbering: Proceedings of SPIE follow an e-First publication model, with papers published first online and then in print. Papers are published as they are submitted and meet publication criteria. A unique citation identifier (CID) number is assigned to each article at the time of the first publication. Utilization of CIDs allows articles to be fully citable as soon as they are published online, and connects the same identifier to all online, print, and electronic versions of the publication. SPIE uses a six-digit CID article numbering system in which:

- The first four digits correspond to the SPIE volume number.

- The last two digits indicate publication order within the volume using a Base 36 numbering

system employing both numerals and letters. These two-number sets start with 00, 01, 02, 03, 04, $05,06,07,08,09,0 A, 0 B \ldots$. OZ, followed by 10-1Z, 20-2Z, etc.

The CID Number appears on each page of the manuscript. The complete citation is used on the first page, and an abbreviated version on subsequent pages. 


\title{
Contents
}

\author{
ix Authors \\ xiii Conference Committees \\ xvii Introduction
}

\section{PLENARY SESSION}

925802 Introduction to compressive sensing and applications in $\mathrm{THz}$ imaging (Plenary Paper) [9258-142]

925803 Alternative applications of the method of moments: from electromagnetic waves to source synthesis, deconvolution, and data processing in navigation systems (Plenary Paper) [9258-33]

925804 Advanced intelligent control methods in open architecture systems for cooperative works on four nano-micro-manipulators plafform (Plenary Paper) [9258-56]

925805 Photoluminescence of some chalcogenide glasses doped with rare-earth ions (Plenary Paper) [9258-11]

925806 Phenomenological model of growth of $\mathrm{TiO}_{2}$ films for biomedicine (Plenary Paper) [9258-43]

\section{ADVANCED MATERIALS AND NEW TECHNOLOGIES}

925807 Method of azimuthally stable Mueller-matrix diagnostics of blood plasma polycrystalline films in cancer diagnostics [9258-123]

925808 New dielectric elastomers with improved properties for energy harvesting and actuation [9258-126]

925809 Treatment with activated water by GlidArc technology of bacteria producing biofouling [9258-47]

9258 OA Influence of GlidArc treatment on layers formation of biofouling [9258-48]

$9258 \mathrm{OB}$ Advanced educational program in optoelectronics for undergraduates and graduates in electronics [9258-88]

9258 OC A new technology for fishing vessels: the use of ejector expansion refrigeration cycle [9258-6]

9258 OD The azobenzene derivatives [9258-13]

9258 OE Modern techniques and technologies for unbundled access in the local loop [9258-91] 
9258 OF Antenna for passive RFID tags [9258-32]

9258 OG High-efficiency DC-DC converter using GaN transistors [9258-28]

$9258 \mathrm{OH}$ Photoluminescent nanocomposite materials based on SBMA copolymer and CdS [9258-72]

9258 0l Morphological alteration of microwave disinfected acrylic resins used for dental prostheses [9258-112]

9258 0J Design of cross-coupled planar microstrip band-pass filters using a novel adjustment method [9258-89]

\section{DIFFRACTIVE, MICRO-OPTICS, AND OPTICAL SIGNAL PROCESSING}

9258 OK Combining polarimetry and spectropolarimetry techniques in diagnostics of cancer changes in biological tissues [9258-7]

$9258 \mathrm{OL}$ The structure of polarization maps of skin histological sections in the Fourier domain for the tasks of benign and malignant formations differentiation [9258-122]

$9258 \mathrm{OM}$ Steady-state photoconductivity of amorphous (As4 $\left.\mathrm{S}_{3} \mathrm{Se}_{3}\right)_{1-x}: \mathrm{Sn}_{\mathbf{x}}$ films [9258-4]

$9258 \mathrm{ON}$ Optical and Raman spectroscopy of $\left(\mathrm{As}_{4} \mathrm{~S}_{3} \mathrm{Se}_{3}\right)_{1-\mathrm{x}}: \mathrm{Sn}_{\mathbf{x}}$ glasses [9258-5]

925800 Spectrometry techniques in diagnostics of hereditary breast cancer [9258-8]

9258 OP Spectropolarimetry of blood plasma in optimal molecular targeted therapy [9258-9]

$92580 Q$ Optical solutions for unbundled access network [9258-90]

9258 OR Wearable vital parameters monitoring system [9258-30]

9258 OS Electron-beam recording of patterns in chalcogenide films [9258-22]

9258 OT Diffraction patterns from holographic masks generated using combined axicon and helical phase distributions [9258-76]

9258 OU Focusing criterion in digital holographic microscopy image reconstruction [9258-79]

9258 OV Universal logic gate with directional couplers [9258-96]

\section{SENSORS, MICROSYSTEMS, AND INSTRUMENTS}

9258 OW Creating a transducer electronic datasheet using I2C serial EEPROM memory and PIC32based microcontroller development board [9258-67]

9258 0X Tele-monitoring system for water environments [9258-53] 
9258 OY Surface plasmon resonance: concept and applications for nano-sensors and optical active devices [9258-42]

$9258 \mathrm{OZ}$ Wearable sensors for health monitoring [9258-137]

925810 Physical Fourier encoding and compacting of optical data [9258-99]

925811 Reengineering for optimized control of DC networks [9258-121]

925812 A marine direction finding system based on global positioning system [9258-59]

925813 Spine lateral flexion strength development differences between exercises with pelvic stabilization and without pelvic stabilization [9258-104]

925814 Optimal control of real ambient LED lighting powering [9258-105]

925815 Mueller-matrix imaging of laser autofluorescence of biological tissues [9258-120]

925816 Using optical soliton stability for magnetic field measurement [9258-134]

925817 Design of anti-burglar alarm systems [9258-136]

925818 Terahertz range complex refractive index determinations for liquids using ATR [9258-106]

925819 Image stabilization for SWIR advanced optoelectronic device [9258-15]

$92581 \mathrm{~A}$ Aspects regarding the drift of platinum resistance sensors used as reference standards [9258-81]

9258 1B L1 minimization applied to two sparse signals that can be described as sums of elementary functions [9258-98]

9258 1C 1D hyperspectral images of a light emitting diodes array [9258-100]

9258 ID Night vision adapter for an aiming telescope [9258-128]

$92581 \mathrm{E}$ Clicks counting system for a riflescope [9258-129]

$9258 \mathrm{IF} \quad$ Automated platform for determination of LEDs spatial radiation pattern [9258-86]

$92581 G$ Study on electrical and thermal behavior of organic photovoltaic (OPV) cells [9258-124]

$9258 \mathrm{1H}$ Implementation of Hadamard spectroscopy using MOEMS as a coded aperture [9258-117]

$925811 \quad$ Recent developments on surface acoustic wave (SAW) sensors for harsh conditions [9258-97]

$92581 \mathrm{~J} \quad$ Redundant uplink optical channel for visible light communication systems [9258-87] 
9258 1K Measurements of amplitude and frequencies of subwavelength oscillations of atoms using resonance fluorescence of three levels atom in two standing waves [9258-50]

$92581 \mathrm{~L} \quad$ The use of the Rayleigh nanoparticles to diagnose optical currents and optical fields [9258-44]

$92581 \mathrm{M}$ Self-action of continuous laser radiation in a water suspension with light-absorbing particles [9258-45]

9258 IN IR assessment of R134a temperature in circular micro-channels [9258-51]

$925810 \quad$ Roughness effect upon the flow of $R$ 134a refrigerant through rectangular microchannels [9258-52]

$92581 \mathrm{P} \quad$ Heat transfer intensification by increasing vapor flow rate in flat heat pipes [9258-66]

$92581 Q \quad$ Capillary layer structure effect upon heat transfer in flat heat pipes [9258-68]

9258 IR Atomization of liquid droplets in multipoint injection [9258-69]

9258 is Realization of spiral phase plates by 3D lithography [9258-107]

9258 1T Nano-indentation investigations of $\left(\mathrm{As}_{2} \mathrm{Se}_{3}\right)_{1-\mathrm{x}}: \mathrm{Sn}_{\mathrm{x}}$ and $\left(\mathrm{As}_{4} \mathrm{~S}_{3} \mathrm{Se}_{3}\right)_{1-\mathrm{x}}: \mathrm{Sn}_{\mathrm{x}}$ glasses [9258-18]

$92581 \mathrm{U}$ Preparation and characterization of $\mathrm{Ga}_{2} \mathrm{O}_{3}$ and $\mathrm{GaN}$ nanoparticles [9258-21]

$92581 \mathrm{~V}$ Optical characterization of the new nanocomposite SBMA/Eu(TTA) $3\left(\mathrm{Ph}_{3} \mathrm{PO}\right)_{2}$ [9258-25]

9258 IW Preparation and characterization of CdSe colloidal quantum dots by optical spectroscopy and 2D DOSY NMR [9258-77]

MODELING, DESIGN, AND SIMULATION

9258 1X Spectral delay line for display control in swept source OCT [9258-145]

$92581 \mathrm{Y}$ Thermal image filtering by bi-dimensional empirical mode decomposition [9258-60]

925812 Resonant response of electromagnetic scattering from ellipsoid [9258-61]

925820 Analysis and simulation of an automated LED lighting system for pedestrian crosswalk [9258-93]

$925821 \quad$ Smart power supply system for LED street lighting [9258-94]

925822 Frequency analysis of a semi-active suspension with magneto-rheological dampers [9258-54] 
925823 Applications of magneto-rheologic fluids in semi-active suspension systems [9258-57]

925824 Friction coefficient influence upon fluid jet atomization [9258-70]

925825 Investigations on electroluminescent tapes and foils in relation to their applications in automotive [9258-127]

925826 Wireless ZigBee home automation system [9258-119]

925827 A Simulink-modeled PV module and array [9258-17]

925828 Material constraints on high-speed design [9258-85]

925829 Conceiving a hybrid model of a weighting device [9258-20]

$92582 \mathrm{~A}$ Original computer method for the experimental data processing in photoelasticity [9258-63]

$92582 \mathrm{~B}$ The phase problem solving by the use of optical correlation algorithm for reconstructing phase skeleton of complex optical fields [9258-64]

9258 2C CFD analysis of a ball check microvalve [9258-102]

9258 2D Two-way fluid structure interaction analysis of a valveless micropump by CFD [9258-103]

$92582 \mathrm{E} \quad$ Simulation of electron transfer in trimer nanocluster embedded in unstructured nondissipative matrix in external electromagnetic field [9258-16]

$92582 \mathrm{~F} \quad$ Optimized design for an electrothermal microactuator [9258-24]

$92582 \mathrm{G}$ The maximum life expectancy for a micro-fabricated diaphragm [9258-26]

$92582 \mathrm{H} \quad$ Numerical simulations of surface plasmon resonances in metal-chalcogenide waveguides [9258-41]

$925821 \quad$ Pre-layout AC decoupling analysis with Mentor Graphics HyperLynx [9258-58]

$92582 \mathrm{~J}$ The influence of environmental parameters on the optimal frequency in a shallow underwater acoustic channel [9258-109]

9258 2K Security aspects of RFID communication systems [9258-1 18]

9258 2L Modelling and simulation of energy harvesting with solar cell [9258-130]

9258 2M Nanoparticles in Constanta-North Wastewater Treatment Plant [9258-138]

$92582 \mathrm{~N} \quad$ Analogy between mission critical detection in distributed systems and ${ }^{13} \mathrm{C}$ isotope separation column [9258-83]

925820 Power LED efficiency in relation to operating temperature [9258-125]

9258 2P Time evolution of dimethyl carbinol in water vortex rings [9258-139] 
$92582 \mathrm{Q}$ Verification of the windings axial clamping forces for high voltage power transformers by using passively mode-locked fiber lasers [9258-133]

OPTICS-INSPIRED APPROACHES FOR NON-OPTICAL APPLICATIONS: SYSTEMS, DEVICES, AND SIGNAL PROCESSING

$92582 R$ Thermoelectrics (TE) used as detectors of radiation: an alternative calorimetry based on the photothermoelectric (PTE) effect [9258-3]

925825 Spectral characterization of the effect of the amber filters on the color hue of an image [9258-82]

9258 2T Comparative spectral analysis between the functionality of the human eye and of the optical part of a digital camera [9258-95]

$92582 \mathrm{U}$ Practical aspects of the use of three-phase alternating current electric machines in electricity storage system [9258-500]

$92582 \mathrm{~V} \quad$ Optimization of meander line antennas for RFID applications by using genetic algorithm [9258-34]

$9258 \mathrm{2W} \quad$ Optimization of meander line radiators for frequency selective surfaces by using genetic algorithm [9258-40]

9258 2X Direction finding antenna system for spark detection and localization [9258-35]

9258 2Y Planar antenna system for direction finding [9258-37]

$925822 \quad$ A novel space-diversity antenna system [9258-38]

925830 Electric arc localization based on antenna arrays and MUSIC direction of arrival estimation [9258-84]

925831 Improvement of antenna decoupling in radar systems [9258-39]

925832 An integrated plafform for inertial navigation systems [9258-131]

925833 Performance studies of electrochromic displays [9258-135]

925834 An automatic speech recognition system with speaker-independent identification support [9258-116]

925835 A balanced wide-band amplifier for microwave applications [9258-36] 


\title{
Authors
}

Numbers in the index correspond to the last two digits of the six-digit citation identifier (CID) article numbering system used in Proceedings of SPIE. The first four digits reflect the volume number. Base 36 numbering is employed for the last two digits and indicates the order of articles within the volume. Numbers start with 00, 01, 02, 03, 04, 05, 06, 07, 08, 09, OA, OB...0Z, followed by 10-1Z, 20-2Z, etc.

\author{
Abrudean, Mihail, ow \\ Acasandrei, A., OU \\ Achimescu, Emanuel, 12 \\ Alkafaji, Muhammed Salah Sadiq, 0J \\ Alonova, Marina, OK \\ Anchidin, Liliana, 2V, 31 \\ Andronic, Florin, 22, 23 \\ Angelsky, O. V., 1M \\ Anghelina, Florina Violeta, OD \\ Apostol, D., 1C \\ Avram, A. M., Ol \\ Axinte, Tiberiu, 29 \\ Bachinskiy, V. T., 07 \\ Bacîş (Vasile), Irina Bristena, OE, OQ, OR \\ Badea, Matei, ON \\ Bălan, Corneliu, 2P \\ Barba, A., IW \\ Barhalescu, Mihaela, 2A \\ Bărtuşică, Răzvan, 2K \\ Baschir, Laurentiu, $2 \mathrm{H}$ \\ Bazgan, Sergiu, 06, $1 \mathrm{~K}$ \\ Bele, Adrian, 08 \\ Beniuga, Marius, 1P, 1Q, 1R, 22, 23, 24 \\ Berescu, Serban, 2V, 2W, 2X, 2Y, 2Z, 31 \\ Bîndar, Valerică, $2 \mathrm{~K}$ \\ Bita, B. I., Ol \\ Bobirca, Daniel, 32 \\ Boca, Maria Loredana, 2N \\ Boerasu, Iulian, ON \\ Bojin, D., $\mathrm{OH}$ \\ Bordian, Olga, 1V, IW \\ Bradu, Adrian, $1 \mathrm{X}$ \\ Bucuci, Stefania C., 2V, 2W, 2X \\ Bucur, Diana, 28 \\ Bunghez, Raluca, OD \\ Burileanu, Corneliu, 34 \\ Butca, Cristina, $\mathrm{OZ}$ \\ Călimănescu, loan, 2C, 2D, 2F, 2G \\ Caramaliu, Radu Vadim, OR \\ Caranica, Alexandru, 34 \\ Caruntu, George, 03, 32 \\ Chilibon, Irinela, 11 \\ Ciucur, Violeta, $2 \mathrm{U}$ \\ Cocias, Gabriela, 2Y, $2 Z$ \\ Cojocaru, I. A., 06, OH, OM \\ Coltuc, Daniela, 02, $1 \mathrm{H}$ \\ Costea, Aurelian, 17 \\ Craciun, Alexandru, OF, 19, 11 \\ Craciun, Anca-lleana, OF, 19
}

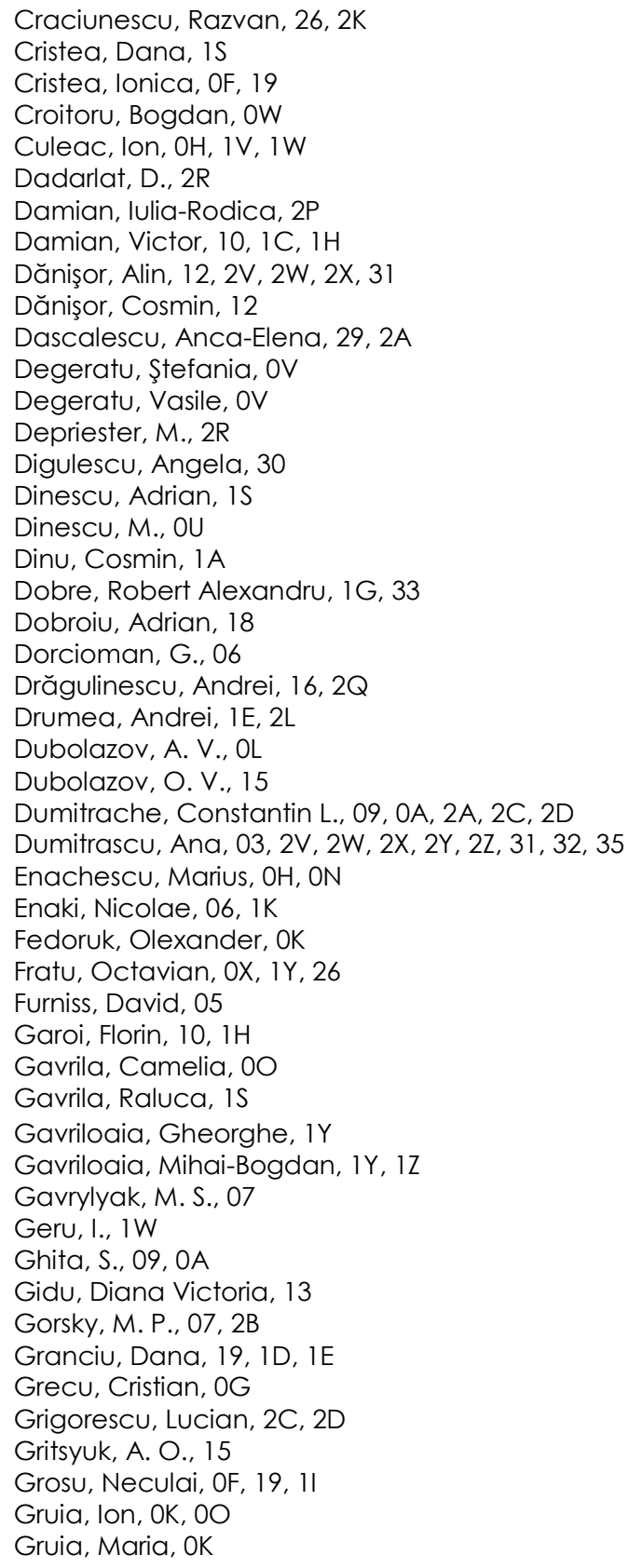


Guilmeau, E., 2R

Hadj Sahraoui, A., 2R

Halunga, Simona, $0 Z, 1 Z, 26,2 K$

Harea, D. V, IT

Harea, E. E., $1 T$

Hnatiuc, B., 09, 0A

Hnatiuc, Mihaela, 09, 0A, 2

laseniuc, Oxana V., OM, ON, OS, IT

llashchuk, Tetjana, OP

lleana, loan, 14, 20, 21

loana, Cornel, 30

Ion, Rodica-Mariana, OD

Ionescu, Ciprian, 1G, 33

Ionita, Ionica, OD

Iordănescu, Raluca, $2 Q$

Iov, Cătălin J., 21

lovu, Mihail S., 05, OH, OM, ON, OS, 1T, IV

Ivanova, Zoya, 05

Ivashko, Pavlo, OK, 00

Izet-Ünsalan, Kunsel-Özel, 12

Kanarovskii, E. Yu., 2E

Karachevtsev, A. O., 15

Kostka, Peter, 05

Kruk, Tetjana, 00

Kuriakose, M., 2R

Kusko, Cristian, OT, IS

Kusko, Mihai, 15

Lazarescu, Vasile, 27

Lazaroiu, Gheorghe, 29

Logofătu, Petre Cătălin, 10, 18, 1B, 1C

Lupan, Elena, 05

Lupescu, Horia, 35

Maignan, A., 2R

Maksimyak, A. P., $1 \mathrm{M}$

Maksimyak, P. P., 1M

Manea, Adrian, OF, 19

Mara, Constantin, $1 Y$

Marc, Gheorghe, 14, 20, 21

Marchuk, Y. F., OL

Mardale, Iulia-Cezara, 2Y, $2 Z$

Marghescu, Cristina, OE, 2L

MarghesCu, Ion, OG

Marinescu, Andrei, 16, 2Q

Memet, Feiza, OC

Micu, Alexandru, 13

Mihai, loan, 1N, 1O, 1P, 1Q, 1R, 22, 23, 24

Mihailescu, Ion, 06, $1 \mathrm{~K}$

Mihăilescu, Mona, $\mathrm{OT}, \mathrm{OU}, 2 \mathrm{H}, 2 \mathrm{P}$

Mihale, N., OU

Militaru, Nicolae, 28

Misse, P. R. N., 2R

Mitricica, Doina-Narcisa, 1D

Mitu, Daniela Elena, OC

Morosanu, Andreea Diana, 1A

Musteata, Valentina, 08

Neagu, Dumitru Marius, $1 \mathrm{~A}$

Neamtu, Catalin, 12

Negutu, Constantin, 2H

Nistor, lurie, $\mathrm{OH}, 1 \mathrm{~V}$

Niță, Valentin Adrian, $1 G$
Novakovskaya, O. Y., OL

Oanta, Emil M., 29, 2A

Ochian, Adelina, OX, OZ

Olar, O. V., OL

Olteanu, Emil, 14

Omocea, loana-Laura, 2P

Panait, Cornel, 29, 2A

Panaitescu, Fanel-Viorel L., 2M

Panaitescu, I. Mariana, $2 M$

Panaitescu, lleana-Irina F. V., 2M

Pantazică, Mihaela, 0G

Panzariu, Mircea, 35

Patuleanu, Liliana, 1N, 10

Paun, I. A., OU

Paun, Mirel, 30

Pellerin, S., OA

Peresunko, Olexander, OK, $0 \mathrm{O}$

Plotog, loan, 25, 20

Podoleanu, Adrian, $1 \mathrm{X}$

Poinescu, Aurora Anca, OD

Poon, Wallace, $1 \mathrm{X}$

Popa, Viorica, 2F, 2G

Popescu, Aurelian A., OY, 2H

Popescu, M. C., Ol

Popescu, Mircea, 2K

Popescu, R. C., OU

Popescu-Pelin, G., 06

Preda, L., OT

Preda, Radu, IY, 12

Prisacar, A. M., OM

Prysyazhnyuk, V.P., 07

Puscas, Niculae N., 2H

Radulescu, Cristiana, OD

Raevschi, S., $1 \mathrm{U}$

Raicu, Alexandra, 29

Risteiu, Mircea, 14, 20, 21

Ristoscu, C., 06

Robu, S., $\mathrm{OH}$

Rosca, T., 06

Rusu, E., 10

Ryabyi, P. A., 2B

Sabau, Adrian, 09, 0A, 2A

Sandru, Ovidiu I., 04

Savastru, Dan, $2 \mathrm{H}$

Savich, V. O., OL

Scarlat, E. I., OT, OU

Schiopu, lonut Romeo, 16, 2Q

\$̧chiopu, Paul, 04, OB, OE, OF, OI, OV, 11, 17, 19, 11

Schultz, David, 1X

Secara, Mihai, $0 \mathrm{~W}, 2 \mathrm{~N}$

Seddon, Angela, 05

Serban, Greta, 1D

Sergeev, S. A., OS

Sidor, M., 15

Simionescu, Ştefan-Mugur, 2P

Sofalca, lonut, 20, 21

Soltys, I. V., $1 \mathrm{~L}$

Sprinceană, Silviu, 1N, 10, 1P, 1Q, 1R, 24

Stafe, Mihai, $2 \mathrm{H}$

Stan, Liviu-Constantin, 2F, 2G 
Stiubianu, George, 08

Straton, Alexandru, 13

Suciu, Cornel, 1N, 1O, 1P, 1Q, 1R, 22, 23, 24

Suciu, George, OX, $0 Z$

Suciu, Victor, OX

Taddy, Emmanuel, 27

Tămas, Razvan D., 03, 12, 2V, 2W, 2X, 2Y, $2 Z, 30,31,32,35$

Tecu, Georgiana Raluca, 0X

Tamaş, Cosmin-Andrei, OG

Toadere, Florin, 1X, 2S, 2T

Tomescu, Roxana, $1 \mathrm{~s}$

Topor, Raluca E., 2X, 31

Trifoniuk, L. I., 15

Tucureanu, V., 01

Tugui, Codrin, 08

Tulbure, Adrian, OW

Turta, C., IW

Udrea, Cristian, 10, 1C, 1H

Ünsalan, Deniz, 12

Ursaki, V., $1 \mathrm{U}$

Urzica (lordache), I., 1C

Ushakova, Olga, 00

Ushenko, A. G., 15

Ushenko, V. A., OL

Ushenko, Yu. A., 07

Vanchuliak, O. Ya., 07

Vasile, Alexandru, OR

Vasile, Georgiana C, $2 \mathrm{H}$

Vasile, T., 1C, $1 \mathrm{H}$

Verlan, Victor, $\mathrm{OH}, 1 \mathrm{~V}, \mathrm{IW}$

Vintea, Adela, 11

Vizireanu, Constantin-Radu, IY, 12

Vizireanu, Dragos-Nicolae, IY

Vladareanu, Luige, 04

Vladareanu, Victor, 04

Vladescu, Marian, OB, OF, 1F, 1G, 1J, 20

Vlazan, P., $1 \mathrm{U}$

Voloshynska, Katerina, 0O, OP

Voloshynskyi, Dmytro, OK

Vuza, Dan Tudor, 1F, $1 \mathrm{~J}$

Wartel, M., 09

Yaltychenko, O. V., 2E

Yermolenko, Sergey, OK, 0O, OP

Zarnescu, George, 2J

Zavadil, Jurii, 05

Zelinska, Natalia, OK

Zenkova, C. YU., 1L, 1M, 2B

Zimnyakov, Dmitry, OK

Zubareva, Vera, IV 
Proc. of SPIE Vol. $9258925801-12$

Downloaded From: https://www.spiedigitallibrary.org/conference-proceedings-of-spie on 26 Apr 2023 Terms of Use: https://www.spiedigitallibrary.org/terms-of-use 


\title{
Conference Committees
}

\author{
Organizing Committee \\ Paul Schiopu, General Chair \\ Cornel Panait, Organizing Committee Chair \\ Violeta-Vali Ciucur, Technical Program Co-chair \\ Razvan Tamas, Technical Program Co-chair \\ Ionica Cristea, Conference General Manager \\ Marian Vladescu, Conference Manager
}

International Committee

Oleg Angelsky, Yuriy Fedkovych Chernivtsi National University (Ukraine)

Claudia Yu. Zenkova, Yuriy Fedkovych Chernivtsi National University (Ukraine)

Hongnian Yu, Bournemouth University (United Kingdom)

Mingcong Deng, Tokyo University of Agriculture and Technology (Japan)

Hong Bo Wang, Yanshan University (China)

Zeng-Guang Hou, Institute of Automation, Chinese Academy of Sciences (China)

Zabih Ghassemlooy, Northumbria University (United Kingdom)

Wen Cai, Guangdong University of Technology (China)

Chunyan Yang, Guangdong University of Technology (China)

Weihua Li, Guangdong University of Technology (China)

John Mo, RMIT University (Australia)

Xianchao Zhao, Shanghai Jiao Tong University (China)

Ramesh Kumar Choudhary, Asia Pacific Institute of Information

Technology (India)

Akhilesh Upahyay, SAGAR Institute of Research, Technology and Science (India)

Mohamed Roushdy, Ain Shams University (Egypt)

Chenkun Qi, Shanghai Jiao Tong University (China)

Sergej B. Yermolenko, Yuriy Fedkovych Chernivtsi National University (Ukraine)

Yury A. Ushenko, Yuriy Fedkovych Chernivtsi National University (Ukraine)

Erchin Serpedin, Texas A\&M University (United States)

Eugene Curatu, Alcon Laboratories (United States)

Daniela Reyna, LAAS-CNRS INSA (France)

Mircea Guina, Tampere University of Technology (Finland)

Cornel loana, Gipsa-Laboratoire, Université de Grenoble (France) 
Gabriel Vasile, Gipsa-Laboratoire, CNRS (France)

Henri Arsenault, Université Laval (Canada)

Radu Malureanu, Technical University of Denmark (Denmark)

Mihail lovu, Institute of Applied Physics, Academy of Sciences of

Moldova (Republic of Moldova)

Nicolae Enachi, Institute of Applied Physics, Academy of Sciences of Moldova (Republic of Moldova)

Paul Schiopu, Politehnica University of Bucharest (Romania)

Radu I. Munteanu, Technical University of Cluj Napoca (Romania)

Luige Vladareanu, Romanian Academy, Bucharest (Romania)

Alexandru Stancu, Alexandru loan Cuza University (Romania)

Dan Apostol, National Institute for Laser Plasma and Radiation Physics (Romania)

Vasile Sarbu, Ovidius University of Constanta (Romania)

Cornel Panait, Constanta Maritime University (Romania)

Violeta Ciucur, Constanta Maritime University (Romania)

Razvan Tamas, Constanta Maritime University (Romania)

Victor Ciupina, Constanta Maritime University (Romania)

George Caruntu, Constanta Maritime University (Romania)

Gheorghe Gavriloaia, University of Pitesti (Romania)

Raluca Muller, National Institute for Research and Development in Microtechnologies (Romania)

lleana Cernica, National Institute for Research and Development in Microtechnologies (Romania)

Dana Granciu, SC IOR SA (Romania)

Mihaela Cezarina Hincu, Ovidius University of Constanta (Romania)

Rodica Mehedinti, Ovidius University of Constanta (Romania)

loan Ileana, 1 Decembrie 1918 University of Alba-lulia (Romania)

loan Gruia, University of Bucharest (Romania)

loan Mihai, Stefan cel Mare University of Suceava (Romania)

Adrian Manea, Politehnica University of Bucharest (Romania)

Niculae Puscas, Politehnica University of Bucharest (Romania)

Lucian Balut, Constanta Maritime University (Romania)

George Stanciu, Politehnica University of Bucharest (Romania)

Rifat Capan, Balikesir University (Turkey)

Constantin Grigoriu, National Institute of Laser Plasma and Radiation

Physics (Romania)

Emil Oanta, Constanta Maritime University (Romania)

Dan Popa, Constanta Maritime University (Romania)

Alin Danisor, Constanta Maritime University (Romania)

Ionica Cristea, Politehnica University of Bucharest (Romania)

Neculai Grosu, Politehnica University of Bucharest (Romania)

Alexandru Craciun, Politehnica University of Bucharest (Romania)

Marian Vladescu, Politehnica University of Bucharest (Romania) 
Technical Committee

Oleg Angelsky, Yuriy Fedkovych Chernivtsi National University (Ukraine)

Claudia Yu. Zenkova, Yuriy Fedkovych Chernivtsi National University (Ukraine)

Mihail lovu, Institute of Applied Physics, Academy of Sciences of Moldova (Moldova)

Nicolae Enaki, Institute of Applied Physics, Academy of Sciences of Moldova (Moldova)

Radu Malureanu, Technical University of Denmark (Denmark)

Ileana Cernica, National Institute for Research and Development in Microtechnologies (Romania)

Dana Granciu, IOR SA (Romania)

Gheorghe Gavriloaia, University of Pitesti (Romania)

Adrian Manea, Politehnica University of Bucharest (Romania)

Niculae Puscas, Politehnica University of Bucharest (Romania)

Paul Schiopu, Politehnica University of Bucharest (Romania)

Alexandru Vasile, Politehnica University of Bucharest (Romania)

Razvan Tamas, Constanta Maritime University (Romania)

George Caruntu, Constanta Maritime University (Romania)

Dan Popa, Constanta Maritime University (Romania)

Ionica Cristea, Politehnica University of Bucharest (Romania)

Neculai Grosu, Politehnica University of Bucharest (Romania)

Alexandru Craciun, Politehnica University of Bucharest (Romania)

Marian Vladescu, Politehnica University of Bucharest (Romania)

Rodica Constantinescu, Politehnica University of Bucharest (Romania)

Nicolae Militaru, Politehnica University of Bucharest (Romania)

Valentin Feies, Politehnica University of Bucharest (Romania)

Andrei Dragulinescu, Politehnica University of Bucharest (Romania)

Local Organizing Committee

Cornel Panait

Violeta-Vali Ciucur

Georgiana Buzu

Georgiana Radu

Razvan Tamas

George Caruntu

Dan Popa

\author{
Daniela Deacu \\ Alexandru Caranica \\ Mirel Paun \\ Ana Dumitrascu \\ Alexandra Nita \\ Madalina Dragan \\ Elena Nedelcu
}


Session Chairs

Plenary Session

Violeta-Vali Ciucur, Constanta Maritime University (Romania)

Razvan Tamas, Constanta Maritime University (Romania)

Paul Schiopu, Politehnica University of Bucharest (Romania)

Marian Vladescu, Politehnica University of Bucharest (Romania)

$1 \quad$ Advanced Materials and New Technologies

Bogdan Hnatiuc, Constanta Maritime University (Romania)

Ana Maria Catargiu, Petru Poni Institute of Macromolecular Chemistry (Romania)

2 Diffractive, Micro-Optics, and Optical Signal Processing

Dorin Dadarlat, National Research and Development Institute for Isotopic and Molecular Technologies (Romania)

Florin Toadere, University of Kent (United Kingdom)

3 Sensors, Microsystems, and Instruments

Cristian Viespe, National Institute of Laser, Plasma and Radiation Physics (Romania)

Adrian Tulbure, 1 Decembrie 1918 University of Alba lulia (Romania)

Aurelian A. Popescu, National Institute of Research and Development for Optoelectronics INOE 2000 (Romania)

Petre Catalin Logofatu, National Institute for Laser, Plasma and Radiation Physics (Romania)

4 Micro/Nanophotonics and Micro/Nanotechnologies

Nicolae Enaki, Institute of Applied Physics, Academy of Sciences of Moldova (Moldova)

Claudia Yu. Zenkova, Yuriy Fedkovych Chernivtsi National University (Ukraine)

5 Modeling, Design, and Simulation

loan Ileana, 1 Decembrie 1918 University of Alba IUlia (Romania)

Ioan Plotog, Politehnica University of Bucharest (Romania)

Emil M. Oanta, Constanta Maritime University (Romania)

Nicolae Militaru, Politehnica University of Bucharest (Romania)

6 Optics-Inspired Approaches for Non-Optical Applications: Systems,

Devices, and Signal Processing

Cornel loana, Grenoble Institute of Technology (France)

Liviu-Constantin Stan, Constanta Maritime University (Romania)

Mihaela Hnatiuc, Constanta Maritime University (Romania)

Marian Vladescu, Politehnica University of Bucharest (Romania) 


\section{Introduction}

The seventh edition of the International Conference on Advanced Topics in Optoelectronics, Microelectronics, and Nanotechnologies (ATOM-N 2014), was hosted for the fourth time in Constanta, one of the most important academic, cultural, and industrial centers in Romania, located in the historical region of Dobrogea.

The present conference marks 14 years of ATOM-N's existence, during which time it has consistently gathered the youthful spirit, as well as the experience of the most appreciated scientists in the field of micro/nano technology and photonics/optoelectronics-topics that have, nowadays, great scientific applications worldwide.

ATOM-N 2014 took place 21-24 August 2014, and was organized into seven main sessions: Plenary Session; Advanced Materials and New Technologies; Diffractive, Micro-Optics, and Optical Signal Processing; Sensors, Microsystems, and Instruments; Modeling, Design and Simulation; Micro/Nanophotonics and Micro/Nanotechnologies; and Optics-inspired Approaches for Non-optical Applications: Systems, Devices, and Signal Processing. This was the third time in the conference's history when students contributions have been evaluated and awarded.

We received abstracts from scientists all over Europe, Asia and United States (from over 10 countries). Due to the efforts of the scientific and program committees, 121 papers were selected for presentation: 6 invited lectures, 28 oral lectures, and 87 poster papers.

We would like to express our thanks to the organizing committee for their enthusiastic and efficient work, and we extend our warmest thanks to all of the authors who presented their scientific contributions.

We hope that all of the participants of this prestigious meeting had both an interesting professional experience, as well as moments of relaxation, while discovering the multicultural aspects of the academic city of Constanta.

\section{Ionica Cristea \\ Marian Vladescu Razvan Tamas}


Proc. of SPIE Vol. $9258925801-18$

Downloaded From: https://www.spiedigitallibrary.org/conference-proceedings-of-spie on 26 Apr 2023 Terms of Use: https://www.spiedigitallibrary.org/terms-of-use 